\title{
TEACHING WRITING NARRATIVE TEXT USING TWO STAY TWO STRAY (TSTS) METHOD
}

\author{
Lina Nuraeni ${ }^{1}$, Gartika Pandu Bhuana ${ }^{2}$ \\ ${ }^{1}$ IKIP Siliwangi \\ ${ }^{2}$ IKIP Siliwangi \\ 112inanuraeni@student.ikipsiliwangi.ac.id, 2 gartikapandu@gmail.com
}

\begin{abstract}
Writing is part important of language. One important skill that should be mastered by the students. The fact show that most of the student find the difficulties in writing. The problems are related to their motivation and technical problem. The method is belief to be able to improve students writing skill. Therefore, the aims of the research is to investigate the application of Two Stay Two Stray (TSTS) method to improve students writing ability. This research used quantitative method.The population of this research was all tenth grade students at one of vocational schools in Cimahi. The sample was eightheen students of class X TKJ. The instrument used test.The result showed that the mean scores of pretest was 63.94 and of posttest was 73.88. From this data it can be concluded after students learned writing narrative text using Two Stay Two Stray (TSTS) method, their writing skill were improved.
\end{abstract}

Keywords: Two Stay Two Stray (TSTS), Narrative Text, Writing Skill

\section{INTRODUCTION}

Writing is one aspect of the language. Writing is hard skillto learn because writing is anactivityin creating text (Hanafiawi, Muharam, \& Parmawati, 2020). It is the process of pouring ideas in mind into the form of writing. A method that represents the language and visual that is writing (Virdyna, 2016). Through writing, a writer can convey information or messages that are useful to the reader.She or he also can deliver what his or her fell. Process of writing is not easy. The writer should think about the topic she or he wants to write. She or he also have to find information about the topic. Writing needs a long process, by which the writer have to find the idea and arrange this idea into words, sentences and paragraph using brain and hand(Izzati \& Faculty, 2018).

As writing need a long process, some students find it difficult to learn. Most of them hve problems that are related to technical problem and motivation. In technical problem, for instance, the students are hard to find the idea for their writing.Pertinent to the real practice in writing class, the effectiveness of using comic strips is indicated (Purwanitasari (2010) and Lutfifati (2011)). This is probably caused by their low reading habit. Students also cannot recognize well the genre of the text. When teacher ask them to make a narrative text, for example, they are still confused to its generic structure. They cannot use the correct tense.They are even hard to make a good sentence. All of these problems are finally impacted to their motiavation in writing. They consider writing as a hard skill to learn.To solve the above problem, the teacher can use Two Stay Two Stray (TSTS) technique. This technique developed by Kagan( in Rusdiana, 2017). It asks the students to work in a group, and provides an opportunity for each group to share the result of discussion with other group. TSTS can be used in writing for all students level. There are eight procedures in using this technique: 1) The teacher divides students into groups in which each the group consists of four students. Group 
formed are heterogeneous or random groups (one group consists of 1 high-ability students, two capable students medium, and one student with low ability). This is done because that method aims to give students opportunities to each other to do mutual support. 2) The teacher provides the sub-subject of each group to be discussed together with member of the group. 3) The students make acooperative with their group. This aims to provide the opportunity to students to be able to actively act in the thinking process.4) After group discussion is completed, two people from each group left the group and see another groups' work. 5) Two people living in groups are in charge of sharing their work and information to guests from other groups. 6) Guests are pleading and self back to their own group to report their findings from other groups. 7) Group matching and discussing their work. 8) Each group presented work outcomes.

The method is group learning system with the aims that students can work together, be responsible, help each other solve problems and encourage to achievement, and train students to socialize( Huda cited in Saputro : 2019). It can make learning process to be meaningfull and students have responsible in process learning. The students are prompted to express studentsopinion. It increases students confidence. It also improves students understanding of the material. Then, it helps to improve the interest and achievement in learning.

Based on the above explanation, this study aims to investigatethe application of Two Stay Two Stray (TSTS) method to improve students'writing ability. Narative text is chosen as some of the students have a problem in creating this text. Narative text is a kind of text that tells the activities or events happened in the past. It shows problematic experience and resolution. The aims is to give a moral lesson to the readers( Pardyonocited in Purba : 2018). Regarding the generic structure, narrative text consists of :

Orientation : Sets the scene and introduces the partici-pants.

Evaluation : A step back evaluate the plight.

Compilation : A crisis arises.

Resolution : The crises is revolved, for better or for worse.

Re-orientation : Optional.

\section{METHOD}

This study was conducted by using quantitative method. Quantitative method is method that used numbers as a tool that must be analizedto get informaion. The design used was preexperimental, especially one group pretest-posttest.The population wereall tenth grade students at a vocational school in Cimahi. The sample was 18 (eighteen) students at TKJ class. Istruments used in this research was test that was divided into two: pretest and posttest. The result of the test was counted by using SPPS.

Regarding the hypothesis, there are two hypothesis:

1. Ha: There is an improvement of students' writing narrative text after the implementation of Two Stay Two Stray.

2. Ho: There is no improvement of students' writing narrative text after the implementation of Two Stay Two Stray.

\section{RESULTS AND DISCUSSION}

\section{Results}

The pretest was given before the treatment was conducted. The aim was to know the students' prior writing ability. Meanwhile, posttest was given after the treatment was performed. The aim was to investigate the improvement of students' writing ability. The result of students' pretest and posttest can be seen below: 
Table 1

Scores of Pretest and Posttest

\begin{tabular}{|c|c|c|c|}
\hline \multirow[t]{2}{*}{ No } & \multirow[t]{2}{*}{ Student } & \multicolumn{2}{|l|}{ Scores } \\
\hline & & Pretest & Posttest \\
\hline 1 & Std 1 & 60 & 70 \\
\hline 2 & Std 2 & 65 & 70 \\
\hline 3 & Std 3 & 55 & 65 \\
\hline 4 & Std 4 & 65 & 75 \\
\hline 5 & Std 5 & 75 & 80 \\
\hline 6 & Std 6 & 70 & 75 \\
\hline 7 & Std 7 & 55 & 70 \\
\hline 8 & Std 8 & 65 & 75 \\
\hline 9 & Std 9 & 60 & 70 \\
\hline 10 & Std 10 & 70 & 85 \\
\hline 11 & Std 11 & 55 & 65 \\
\hline 12 & Std 12 & 65 & 75 \\
\hline 13 & Std 13 & 60 & 75 \\
\hline 14 & Std 14 & 70 & 80 \\
\hline 15 & Std 15 & 60 & 75 \\
\hline 16 & Std 16 & 65 & 70 \\
\hline 17 & Std 17 & 70 & 80 \\
\hline 18 & Std 18 & 65 & 75 \\
\hline To & & 1150 & 1330 \\
\hline Me & & 63.94 & 73.88 \\
\hline $\mathrm{Mc}$ & & 75 & 85 \\
\hline $\mathbf{M i}$ & & 55 & 65 \\
\hline
\end{tabular}

The result showed that the mean scores of pretest was 63.94 and the mean scores of posttest was 73.88.This indicated that there was the difference between the score of pretest and posttest. In this case, the result of post-test was higher than pretest. This mean there was an improvement of student score after getting the treatment.

\section{Discussion}

\section{Table normality test}

\begin{tabular}{lllllll}
\hline \multicolumn{1}{l}{ Tests of Normality } \\
& \multicolumn{7}{l}{ Kolmogorov-Smirnov ${ }^{\mathrm{a}}$} & \multicolumn{3}{l}{ Shapiro-Wilk } \\
\cline { 2 - 7 } & Statistic & df & Sig. & Statistic & df & Sig. \\
\hline pretest & .187 & 18 & .097 & .924 & 18 & .154 \\
\hline posttest & .212 & 18 & .031 & .933 & 18 & .220 \\
\hline \multicolumn{7}{l}{ a. Lilliefors Significance Correction } \\
\hline
\end{tabular}

Normality test was used to know the normality of the data. As the sample of this study was below 32, Kolmogororv-Smirnov was used. Based on the table, the significance value of pretest 
(0.097) and postest (0.031) was higher that 0.05 . This indicated that the data of this research was normally distributed.

\section{Table Homogenity test}

\begin{tabular}{|c|c|c|c|}
\hline \multicolumn{4}{|c|}{ Test of Homogeneity of Variances } \\
\hline pretest & & & \\
\hline $\begin{array}{l}\text { Levene } \\
\text { Statistic }\end{array}$ & & df2 & Sig. \\
\hline .736 & 3 & 12 & .551 \\
\hline
\end{tabular}

Homogenity test was used to find out the distribution of the data. The result showed that the signifcane value was 0.551 . As this value is greater than 0.05 , the data was homogen.

Table T-test

\begin{tabular}{|c|c|c|c|c|c|c|c|c|c|}
\hline \multicolumn{10}{|c|}{ Paired Samples Test } \\
\hline & & \multicolumn{2}{|c|}{ Paired Differences } & \multirow{3}{*}{$\begin{array}{l}\text { Std. Error } \\
\text { Mean }\end{array}$} & & & \multirow{3}{*}{$-\mathrm{t}$} & \multirow[t]{3}{*}{ df } & \multirow{3}{*}{$\begin{array}{l}\text { Sig. (2) } \\
\text { tailed) }\end{array}$} \\
\hline & & \multirow[t]{2}{*}{ Mean } & \multirow[t]{2}{*}{$\begin{array}{l}\text { Std. } \\
\text { Deviation }\end{array}$} & & $\begin{array}{l}95 \% \\
\text { Interval } \\
\text { Difference }\end{array}$ & $\begin{array}{l}\text { Confidence } \\
\text { of the } \\
\text { of }\end{array}$ & & & \\
\hline & & & & & Lower & Upper & & & \\
\hline Pair 1 & $\begin{array}{l}\text { pretest } \\
\text { menulis } \\
\text { posttest }\end{array}$ & --10.500 & 3.312 & .781 & -12.147 & -8.853 & -13.450 & 17 & .000 \\
\hline
\end{tabular}

T-test was used to investigate the significance difference between two means. The result showed that the significance (2-tailed) value was 0.000. This was lower than 0.05. Then Ho was rejected and Ha was accepted. In other words, Two Stay Two Stray (TSTS) can improve students' ability in writing narrative text.

\section{CONCLUSION}

The application Two Stay Two Stray (TSTS) method is effective to make students to increase their ability in writing narrative text. This can be seen from the score of posttest(73.88) which is higher than the mean score of pretest (63.94). This data is strengthen by the result of t-test which show the significance 2-tailed (0.000) which is lower than 0.05 .

Two Stay Two Stray (TSTS) is effective in improving students' writing narrative skill since it can increase students's understanding of the material. As previously discussed that in this technique, the student is allowed to discuss the material with their group. They also see the other works from the other groups. It directly provides the opportunity for them to be actively act in thingking process.

\section{ACKNOWLEDGMENTS}

All prises be to Allah, which has given strength and health and also to complete this journal. Pace and salutation be upon the prophet Muhammad SAW, his family and his companion and adherence. As well as family and friends who have provided motivation to me to complete this journal until the finish. 


\section{REFERENCES}

Hanafiawi, D., Muharam, H., \& Parmawati, A. (2020). The Use Of Clustering Technique To Improve Students'skill In Writing Descriptive Text. PROJECT (Professional Journal of English Education), 3(1), 5-10.

Izzati, N. (2018). The influence of students' imagination toward their writing skill of descriptive text (Doctoral dissertation, UIN Walisongo).

Megawati, F., \& Anugerahwati, M. (2012). Comic Strips: a study on the teaching of writing narrative texts to Indonesian EFL students. Teflin Journal, 23(2), 183-205.

Purba, R. (2018). Improving the achievement on writing narrative text through discussion starter story technique. Advances in Language and Literary Studies, 9(1), 27-30.1

Virdyna, N. K. (2016). Teaching writing skill by using brainwriting strategy. OKARA: Jurnal Bahasa dan Sastra, 10(1), 67-77. 